\title{
HUBUNGAN KINERJA PENYULUH PERTANIAN DENGAN KOMPETENSI PETANI KAKAO DALAM PENINGKATAN PRODUKTIVITAS KAKAO DI KOTA PALOPO, KABUPATEN LUWU, LUWU UTARA DAN LUWU TIMUR
}

\author{
Sapar $^{1}$ \\ Muhammad Yusuf $Q^{2}$ \\ Haedar $^{3}$
}

No. HP $081317040503^{1}, 08124211468^{2}, 081342701659^{3}$

\section{ABSTRAK}

Tujuan jangka panjang penelitian ini adalah peningkatan kemampuan petani dalam berusahatani kakao sehingga berdampak pada peningkatan produktivitas kakao sehingga para petani kakao semakin sejahtera secara ekonomi, sosial dan budaya. Kinerja penyuluh pertanian yang baik berdampak pada perbaikan kinerja petani dalam memproduksi kakao. Kinerja penyuluh ini terarah pada pemecahan masalah yang dihadapi oleh petani dalam melaksanakan usahatani kakao.

Target khusus yang ingin dicapai dalam penelitian ini adalah: (1) menjelaskan hubungan kompetensi penyuluh terhadap kinerja mereka dan (2) menjelaskan hubungan kinerja penyuluh pertanian terhadap kompetensi petani kakao di empat wilayah Sulawesi Selatan.

Metode yang digunakan dalam penelitian ini adalah metode survey, dengan menjadikan angket sebagai bahan utama mengumpulkan data. Populasi dalam penelitian ini adalah seluruh penyuluh pertanian di kota Palopo, Kabupaten Luwu, Luwu Utara dan Luwu Timur yang berjumlah 447 penyuluh pertanian dan petani kakao yang menjadi binaan penyuluh. Dengan menggunakan metode proporsional random sampling dan rumus Slovin dengan tingkat kepercayaan $95 \%$, sampel penelitian ini berjumlah 106 penyuluh pertanian dan 106 petani kakao yang menjadi binaan penyuluh. Hasil uji validitas dan reliabilitas untuk kuisioner kinerja penyuluh sebesar 0,93, dan kompetensi petani kakao 0,70. Data yang diperoleh dianalisis dengan regresi linear sederhana menggunakan program SPSS 16.0

Hasil penelitian menunjukkan bahwa Persamaan regresi sederhana adalah: $Y=90,461$ + 0,410X, peubah kinerja penyuluh pertanian berpengaruh terhadap kompetensi petani kakao sebesar 0,410 satuan.

Kesimpulan penelitian ini adalah kinerja penyuluh pertanian berpengaruh positif dan signifikan terhadap kompetensi petani kakao, sehingga disarankan kepada pemerintah daerah cq Badan ketahanan pangan dan penyuluhan pertanian pemerintah setempat untuk selalu berfokus pada peningkatan kompetensi penyuluh melalui program-program pelatihan teknis budidaya kakao untuk menunjang kinerja penyuluh untuk peningkatan kompetensi petani kakao.

Keywords: kinerja penyuluh, kompetensi petani kakao.

\section{PENDAHULUAN}

Kakao merupakan salah satu produk pertanian yang memiliki peranan yang cukup nyata dan dapat diandalkan dalam mewujudkan program pembangunan pertanian, khususnya dalam hal penyediaan lapangan kerja, pendorong pengembangan wilayah, peningkatan kesejahteraan petani, dan pendapatan/devisa Negara.

Pengusahaan kakao di Indonesia sebagian besar merupakan perkebunan rakyat di desa-desa yang tersebar di hampir seluruh provinsi di tanah air sehingga agribisnis kakao secara langsung berkesinambungan dengan kesejahteraan masyarakat kecil di pedesaan. Dalam dua dasawarsa terakhir ini, areal kakao rakyat terus mengalami pertumbuhan yang nyata sehingga produksi kakao nasional juga terus 
meningkat seiring dengan peningkatan luas arealnya.

Penyuluh pertanian kakao sebagai bagian dari sistem pembangunan pertanian, memiliki peran strategis dalam membantu petani kakao meningkatkan produktivitas kakao. Sebagai bagian dari pendidikan non formal bagi petani kakao dan keluarganya, penyuluhan berperan dalam memberikan pendidikan agar petani kakao dapat memperbaiki kemampuannya dalam berusahatani kakao. Oleh karena itu, penelitan tentang hubungan kinerja penyuluh pertanian terhadap kompetensi petani kakao dalam peningkatan produktivitas petani kakao memiliki peran yang sangat penting untuk membantu seluruh stakeholder pertanian kakao memperoleh informasi ilmiah dalam membangun pertanian kakao dimasa yang akan datang.

penyuluh pertanian adalah "pemandu" yang memandu pengusaha dan pedagang untuk menemukan ilmu dan teknologi yang mereka butuhkan untuk memecahkan masalah yang mereka hadapi. Dalam proses kepemanduan, petani, pengusaha dan pedagang pertanian bukan sebagai "murid" tetapi "mitra belajar" yang melakukan proses belajar. Hasilnya adalah petani, pengusaha dan pedagang pertanian yang berkualitas sebagai manusia pembelajar, manusia peneliti, manusia penyelenggara agribisnis, manusia pemimpin, dan manusia pemandu petani/pengusaha/pedagang lainnya. Mereka dirangsang untuk belajar agar menjadi berdaya untuk memecahkan masalah.
Kinerja penyuluh pertanian yang tinggi sebagai pemberi dorongan dan pemandu petani bagi terselenggaranya proses belajar pada diri petani tentang budidaya kakao dan partisipasi petani dalam kelompok diharapkan akan terjadi pada peningkatan kompetensi petani dalam usahatani kakao. Peningkatan kompetensi petani kakao dalam usahataninya seperti kompetensi usahatani kakao (persiapan lahan, pemangkasan, pemupukan, pengendalian hama, penyakit dan gulma, serta panen dan pasca panen), kemampuan berpartisipasi dalam penyuluhan dan kelompok tani, kemampuan merencanakan usaha (planning), kemampuan mengorganisir dan memasarkan hasil (marketing), kemampuan keuangan (financial), kemampuan berkomunikasi dan memotivasi, kemampuan membentuk kelembagaan ekonomi, dan kemampuan mengakses pupuk, herbisida dan insektisida, diharapkan akan berdampak pada peningkatan produksi kakao serta kualitas kakao itu sendiri. Peningkatan produksi dan kualitas kakao berpengaruh kepada pendapatan mereka. Bertambahnya pendapatan, maka petani kakao semakin sejahtera hidupnya.

Kompetensi berusahatani adalah salah satu hal yang dapat dijadikan prioritas bagi penyuluh dalam merancang program pembelajaran yang disuluhkan pada petani. Sebagai pendidik dan pemberi semangat, penyuluh harus fokus pada mendidik petani mengembangkan manajemen usahataninya sehingga petani terinspirasi untuk terus melakukan proses pembelajaran. 
Penyuluh pertanian yang berkinerja baik adalah dambaan bagi petani. Penyuluh yang berkinerja baik dilihat pada petani yang mampu memecahkan masalahnya. Peningkatan pengetahuan, sikap dan keterampilan petani dalam usahatani ditentukan oleh kualitas kerja penyuluh pertanian dalam membantu petani.

Berdasarkan latar belakang di atas, maka rumusan masalah penelitian ini adalah berapa besar hubungan kinerja penyuluh pertanian terhadap kompetensi petani kakao, sedangkan tujuan penelitian ini adalah menjelaskan hubungan kinerja penyuluh pertanian terhadap kompetensi petani kakao.

\section{Metode Penelitian}

Pengumpulan data dilakukan di Kota Palopo, Kabupaten Luwu, Luwu Utara dan Kota Palopo. Pengumpulan data dilakukan pada bulan Februari - Juli tahun 2014.

Populasi penelitian adalah seluruh penyuluh pertanian dan petani kakao binaan penyuluh di Kabupaten Luwu, Luwu Timur, Luwu Utara dan Kota Palopo, Sulawesi Selatan yang berjumlah 447 orang.

Sampel diambil secara proporsional random sampling dari seluruh penyuluh. Ukuran sampel setiap daerah ditentukan secara proporsional sesuai dengan jumlah penyuluh pertanian yang terdapat di setiap daerah secara acak.

Dengan menggunakan rumus Slovin (Sevilla, 1993), ukuran sampel penyuluh pertanian dengan tingkat kesalahan lima persen sebesar 106 penyuluh pertanian dengan komposisi masing-masing daerah adalah Kota Palopo 22 penyuluh, Kabupaten Luwu 34 penyuluh, Kabupaten Luwu Utara 26 penyuluh, Kabupaten Luwu Timur 24 penyuluh pertanian. Sampel untuk petani kakao diwakili oleh para petani kakao yang menjadi binaan penyuluh yang dijadikan sampel.

Jenis penelitian ini adalah "ex post facto," yaitu bentuk penelitian untuk menilai peristiwa yang telah terjadi untuk menemukan faktor-faktor penyebab melalui pengamatan atau penilaian kondisi faktual di lapangan, Metode yang digunakan dalam penelitian ini adalah metode survey. Pengambilan data dilakukan melalui wawancara dan pengisian kuisioner. Hasil uji validitas dan reliabilitas untuk kuisioner kinerja penyuluh sebesar 0,93, dan kompetensi petani kakao 0,70.

Regresi Linier Sederhana digunakan dalam analisis data dengan formula sebagai berikut:

$\mathrm{Y}=\mathrm{a}+\mathrm{bX}$

Dimana:

$$
\begin{aligned}
& Y=\text { Kinerja Penyuluh Pertanian } \\
& X=\text { Kompetensi Penyuluh Pertanian } \\
& a=\text { Konstanta } \\
& b=\text { Kemiringan }
\end{aligned}
$$

\section{HASIL PENELITIAN}

\section{Analisis Regresi Sederhana}

Berikut ini adalah uraian hasil pengujian regresi sederhana antara kinerja penyuluh pertanian dengan kompetensi petani kakao dan output tabel coefficient pengujian dengan menggunakan bantuan program SPSS versi 16. 


\section{Tabel 1}

\section{Koefisien antara Kinerja Penyuluh Pertanian dengan Kompetensi Petani Kakao}

\begin{tabular}{|c|c|c|c|c|c|c|}
\hline \multicolumn{7}{|c|}{ Coefficients $^{a}$} \\
\hline \multirow{2}{*}{\multicolumn{2}{|c|}{ Model }} & \multicolumn{2}{|c|}{ Unstandardized Coefficients } & $\begin{array}{c}\text { Standardized } \\
\text { Coefficients }\end{array}$ & \multirow[b]{2}{*}{$\mathrm{t}$} & \multirow[b]{2}{*}{ Sig. } \\
\hline & & B & Std. Error & Beta & & \\
\hline \multirow[t]{2}{*}{1} & (Constant) & 90.461 & 32.302 & & 2.800 & .007 \\
\hline & KINERJA & .312 & .102 & .410 & 3.051 & .004 \\
\hline
\end{tabular}

a. Dependent Variable: KOMPETENSI PETANI KAKAO

Tabel 2

Annova antara Kinerja Penyuluh Pertanian dengan Kompetensi Petani Kakao

ANOVA $^{\mathrm{b}}$

\begin{tabular}{|rl|r|r|r|r|r|}
\hline Model & & Sum of Squares & Df & Mean Square & \multicolumn{1}{c|}{ F } & \multicolumn{1}{c|}{ Sig. } \\
\hline 1 & Regression & 105597.834 & 1 & 15957.834 & 9.308 & $.004^{\mathrm{a}}$ \\
& Residual & 78860.478 & 104 & 1714.358 & & \\
& Total & 94818.312 & 105 & & & \\
\hline
\end{tabular}

a. Predictors: (Constant), KINERJA PENYULUH

b. Dependent Variable: KOMPETENSI PETANI

Tabel 3

Koefisien Determinasi antara Kinerja Penyuluh Pertanian dengan Kompetensi Petani

Kakao

Model Summary

\begin{tabular}{|l|r|r|r|r|}
\hline Model & $\mathrm{R}$ & \multicolumn{1}{|c|}{ R Square } & \multicolumn{1}{c|}{ Adjusted R Square } & \multicolumn{1}{c|}{$\begin{array}{c}\text { Std. Error of the } \\
\text { Estimate }\end{array}$} \\
\hline 1 & $.410^{\mathrm{a}}$ & .168 & .150 & 41.405 \\
\hline
\end{tabular}

a. Predictors: (Constant), KOMPETENSI 
Berdasarkan pada tabel 1, 2 dan 3 diatas, dapat diketahui nilai koefisien regresi, koefisien determinasi, nilai $F$ hitung, $t$ hitung , signifikansi dan sebagainya antara kinerja penyuluh pertanian terhadap kompetensi petani kakao. Penjelasan hasil analisis regresi dan pengujian $\mathrm{t}$ dan $\mathrm{F}$ sebagai berikut:

1. Analisis Regresi Linear Sederhana

Persamaan regresi sederhana adalah:

$$
\begin{aligned}
& Y=a+b X \\
& Y=90,461+0,410 X
\end{aligned}
$$

Keterangan:

$\mathrm{Y}=$ Kompetensi Petani Kakao

$X=$ Kinerja Penyuluh Pertanian

$\mathrm{a}=$ Nilai Konstanta

$\mathrm{b}=$ Koefisien Regresi

Penjelasan persamaan tersebut sebagai berikut:

a. Konstanta sebesar 90,461; artinya jika kinerja penyuluh pertanian nilainya 0 , maka kompetensi petani kakao nilainya positif sebesar 90,461 .

b. Koefisien regresi kompetensi penyuluh pertanian sebesar 0,410 ; artinya jika kinerja penyuluh pertanian mengalami kenaikan satu satuan, maka kompetensi petani kakao akan mengalami peningkatan sebesar 0,410 satuan. Koefisien bernilai positif artinya hubungan antara kinerja penyuluh pertanian dengan kompetensi petani kakao adalah positif, artinya semakin tinggi kinerja penyuluh pertanian maka semakin meningkatkan kompetensi petani kakao.

\section{Pengujian Hipotesis}

\section{Uji t (Uji koefisien regresi sederhana)}

Uji t digunakan untuk mengetahui pengaruh secara signifikan antara kinerja penyuluh pertanian dengan kompetensi petani kakao.

Langkah-langkah pengujian hipotesis sebagai berikut:

1. Menentukan hipotesis:

H0: Kinerja penyuluh pertanian tidak berpengaruh terhadap kompetensi petani kakao.

$\mathrm{Ha}$ : Kinerja penyuluh pertanian berpengaruh terhadap kompetensi petani kakao.

2. Menentukan tingkat signifikansi: Tingkat signifikansi menggunakan 0,05

3. Menentukan t hitung: Berdasarkan Tabel di atas diperoleh t hitung sebesar 3,051

4. Menentukan $\mathrm{t}$ tabel: Tabel distribusi $\mathrm{t}$ dicari pada $\alpha=5 \%: 2=2,5 \%$ (uji 2 sisi) dengan derajat kebebasan (df) n-k-1 atau 106-1-1 = 104 ( $n$ adalah jumlah data dan $\mathrm{k}$ adalah jumlah variabel bebas. Dengan pengujian 2 sisi (signifikansi $=0,025$ ) hasil diperoleh untuk $t$ tabel sebesar 1,679 .

5. Kriteria pengujian:

Ho diterima jika $\mathrm{t}$ tabel $\leq \mathrm{t}$ hitung $\leq \mathrm{t}$ tabel. Ho ditolak jika t hitung $<\mathrm{t}$ tabel atau $\mathrm{t}$ hitung $>\mathrm{t}$ tabel. 
6. Membandingkan t hitung dengan t tabel: nilai $t$ hitung $>$ t tabel $(3,051>1,679)$ maka Ho ditolak.

7. Kesimpulan:

Karena nilai $t$ hitung $>\mathrm{t}$ tabel $(3,051>$ 1,679) maka Ho ditolak, artinya bahwa kinerja penyuluh pertanian berpengaruh terhadap kompetensi petani kakao. Nilai t hitung positif, artinya semakin tinggi kinerja penyuluh pertanian maka semakin meningkatkan kompetensi petani kakao.

Langkah-langkah pengujian hipotesis sebagai berikut:

1. Menentukan hipotesis:

HO: Kinerja penyuluh pertanian tidak berpengaruh terhadap kompetensi petani kakao.

Ha: Kinerja penyuluh pertanian berpengaruh terhadap kompetensi petani kakao.

2. Menentukan tingkat signifikansi: Tingkat signifikansi menggunakan 0,05

3. Menentukan signifikansi. Berdasarkan tabel diatas diperoleh nilai signifikansi sebesar 0,04.

4. Kriteria pengujian:

Ho diterima jika signifikansi $>0,05$

Ho ditolak jika signifikansi $<0,05$

5. Membandingkan signifikansi. Nilai signifikansi 0,04 kurang dari 0,05, maka Ho ditolak

6. Kesimpulan:

Karena nilai signifikansi 0,04 kurang dari 0,05 maka Ho ditolak, artinya bahwa kinerja penyuluh pertanian berpengaruh terhadap kompetensi petani kakao.

\section{Pembahasan Penelitian}

Pembahasan difokuskan pada penjelasan mengenai temuan penelitian ini. Hal ini dilakukan dengan memperhatikan kembali data dan informasi yang didapat dari lokasi penelitian dan teori serta hasil penelitian yang menunjang.

\section{Pengaruh Kinerja Penyuluh Pertanian terhadap Kompetensi Petani Kakao}

Hasil penelitian menunjukkan bahwa peubah kinerja penyuluh pertanian berpengaruh nyata terhadap kompetensi petani kakao. Kinerja penyuluh pertanian ikut menentukan baik buruknya kompetensi petani kakao dengan koefisien pengaruh sebesar 0,410 satuan pada $\alpha 0,05$

Pengaruh kinerja penyuluh pertanian terhadap kompetensi petani kakao tersebut tampak pada baik buruknya kemampuan usahatani kakao, kemampuan berpartisipasi dalam penyuluhan dan kelompok tani, kemampuan merencanakan usaha, kemampuan mengorganisir dan memasarkan hasil, kemampuan keuangan, kemampuan berkomunikasi dan memotivasi, kemampuan membentuk kelembagaan ekonomi dan kemampuan mengakses pupuk, herbisida dan insektisida. Jika terjadi peningkatan satu satuan kinerja penyuluh pertanian akan meningkatkan kompetensi petani kakao sebesar 0,410 satuan pada $\alpha 0,05$.

Kemampuan usahatani kakao meliputi kemampuan mempersiapkan lahan kakao, kemampuan membibitkan lahan kakao, kemampuan menanam kakao, kemampuan 
mengkonversi dan menyiapkan lahan, kemampuan memangkas kakao, kemampuan memupuk, kemampuan mengendalikan hama, penyakit dan gulma.

Kemampuan berpartisipasi dalam penyuluhan dan kelompok tani meliputi kemampuan aktif membayar iuran anggota, kemampuan untuk aktif hadir di setiap pertemuan, kemampuan menyumbangkan pemikiran dalam kelompok tani, kemampuan mengikuti kegiatan penyuluhan pertanian.

Kemampuan merencanakan usaha meliputi kemampuan menghubungkan kebutuhan dan kenyataan untuk menentukan target atau tujuan usahatani kakao, kemampuan merumuskan rangkaian tindakan dalam usahatani kakao, dan kemampuan menguasai kalkulasi keuangan dan analisis usaha.

Kemampuan mengorganisir dan memasarkan hasil meliputi kemampuan membagi pekerjaan dan tanggungjawab, kemampuan menguasai informasi dan membuat profil pasar, kemampuan membaca fluktuasi dan harga kakao, kemampuan memutuskan waktu yang tepat menjual kakao, dan kemampuan menjual produk pada pasar berbeda dengan harga menguntungkan.

Kemampuan keuangan meliputi kemampuan menabung, kemampuan mengakses kredit usahatani kakao, kemampuan membuat pembukuan usahatani kakao, dan kemampuan membaca prospek keuangan usahatani kakao.
Kemampuan

membentuk kelembagaan ekonomi meliputi kemampuan membentuk kelompok tani, kemampuan membentuk kopersi simpan pinjam.

Kemampuan mengakses pupuk, herbisida dan insektisida meliputi kemampuan mengakses pupuk, herbisida dan insektisida dan kemampuan membuat pupuk, herbisida dan insektisida alami.

Dimensi peubah kinerja penyuluh pertanian yang berpengaruh pada proses dan hasil dari pelaksanaan penyuluhan pertanian, terdiri dari :

Persiapan penyuluh pertanian yang meliputi membuat rencana pembelajaran usaha tani kakao; tersusunnya rumusan hasil pengumpulan data potensi wilayah dan agroekosistem; membuat rumusan hasil kebutuhan teknologi spesifik lokasi yang sesuai dengan kebutuhan petani; membuat programa penyuluhan yang mengakomodir kebutuhan petani; menyusun rencana kerja yang jelas, terukur dan terealisasi; dan menyusun metode penyuluhan yang sesuai dengan materi penyuluhan dan karakteristik petani.

Pelaksanaan penyuluhan pertanian meliputi melaksanakan pembelajaran usaha tani kakao; menyuluhkan materi penyuluhan yang sesuai dengan kebutuhan dan karakteritik petani; menerapkan metode penyuluhan yang bervariasi dan sesuai dengan materi penyuluhan dan karakteristik petani dan mengembangkan kelompok tani menjadi kelompok yang lebih besar terkait dengan pengembangan usaha taninya. 
Evaluasi dan pelaporan penyuluhan pertanian meliputi melakukan evaluasi efektivitas program; mengumpulkan data tentang input, aktivitas, kehadiran peserta dan reaksi terhadap program; membuat laporan dan rencana tindak lanjut; mengevaluasi dampak penyuluhan dan mengkomunikasikan hasil evaluasi kepada pihak - pihak terkait.

Pengembangan penyuluhan pertanian meliputi menyusun pedoman teknis dan pelaksanaan penyuluhan untuk acuan penyuluh dalam melaksanakan tugasnya; merumuskan hasil kajian arah kebijakan penyuluhan; dan merumuskan hasil konsep baru metode penyuluhan.

Pengembangan profesi penyuluhan pertanian meliputi ikut serta atau aktif dala perkumpulan profesi tingkat Kabupaten, Provinsi dan Nasional; mengunjungi sumbersumber informasi teknologi pertanian; mengakses informasi menggunakan internet; mengikuti kegiatan magang atau studi banding; dan membuat tulisan ilmiah atau populer dan diterbitkan dalam majalah atau surat kabar.

Kemampuan penyuluhan pertanian meliputi menerapkan gaya kepemimpinan; menerapkan keterampilan memimpin; menumbuh kembangkan kelompok tani; dan mengembangkan kepemimpinan kelompok tani.

Diseminasi teknologi meliputi penggunaan media cetak atau audio visual; melakukan pameran teknologi pertanian; tingkat penggunaan komunikasi tatap muka; melakukan studi banding; dan tingkat penggunaan petak percontohan.

Komunikasi penyuluh pertanian meliputi membuat media penyuluhan; memahami dan mendengarkan petani; menjelaskan, memberi inspirasi, berterima kasih dan toleran terhadap petani; mendorong dan membantu petani untuk maju dan mencapai tujuan; dan mendisiplinkan diri dan memotivasi petani.

Kemitraan usaha meliputi mencari mitra usaha; mengidentifikasi dan menginventarisir sumber-sumber permodalan lokal; membimbing pemupukan modal usaha; dan membimbing penyediaan agro input, penyimpanan dan pemasaran hasil.

Melakukan teknis budidaya kakao meliputi mempersiapkan lahan; membibitkan kakao; melakukan penanaman; melakukan konservasi dan persiapan lahan; melakukan pemangkasan dan pemupukan; melakukan pengendalian hama, penyakit dan gulma; melakukan panen dan pasca penen seperti pemetikan dan sortasi buah kakao, pemeraman atau penyimpanan, pemecahan buah, fermentasi, perendaman dan pencucian buah kakao, pengeringan, tempering dan sortasibuah kakao.

Hasil penelitian ini sejalan dengan hasil penelitian Teddy Rachmat Muliady (2009) yang menyimpulkan bahwa kompetensi penyuluh pertanian berpengaruh positif pada kinerja mereka. Penelitian Bestina et al., (2006) juga mendukung penelitian ini.

Peubah kinerja penyuluh yang berpengaruh nyata pada kompetensi petani 
kakao, memperkuat teori Robbins (Veithzal, 2004), Siagian (2002), Gibson (2001) dan Atmosoeprapto (2004). Keempat teori tersebut pada umumnya menyatakan bahwa kinerja adalah fungsi interaksi antara kemampuan atau ability, motivasi atau motivation dan kesempatan atau opprtunity, tugas yang tepat dan lingkungan kerja. Kemampuan yang tinggi dan didukung oleh motivasi yang tinggi pula akan memberikan sesuatu yang baik berupa produktivitas yang lebih baik (produktif).

Menurut hasil penelitian pengaruh kinerja penyuluh pertanian menyumbangkan pengaruh yang besar pada kompetensi petani kakao. Hal ini ditunjukkan oleh koefisien pengaruh sebesar 0,410 satuan, oleh karena itu peubah kinerja penyuluh pertanian harus dijadikan titik fokus dalam peningkatan kompetensi petani kakao. Dalam hubungan ini kemampuan penyuluh merencanakan program, mengevaluasi dan membuat laporan perlu dikembangkan.

\section{KESIMPULAN DAN SARAN}

Berdasarkan hasil penelitian dan pembahasan, disimpulkan bahwa kinerja penyuluh pertanian berpengaruh nyata dan signifikan terhadap kompetensi petani kakao di Kota Palopo, Kabupaten Luwu, Luwu Utara dan Luwu Timur, sehingga disarankan kepada Badan Ketahanan Pangan dan Penyuluhan Pertanian Kota Palopo, Kabupaten Luwu, Luwu Utara dan Luwu Timur untuk terus meningkatkan kinerja penyuluh pertanian kakao dengan berfokus pada peningkatan kompetensi mereka dengan melakukan berbagai macam pelatihan tentang teknis kakao terhadap penyuluh-penyuluh pertanian agar dapat meningkatkan pengetahuan mereka tentang teknis kakao dan dapat di salurkan kepada seluruh petani kakao binaan penyuluh.

\section{DAFTAR PUSTAKA}

\section{Buku}

Gibson JL. 2001. Cooperative Extension Program Planning in Wisconsin. USA. University of Wisconsin.

Sapar. 2010. Faktor-Faktor yang Memengaruhi Kinerja Penyuluh Pertanian dan Dampaknya pada Kompetensi Petani Kakao di Empat Wilayah Sulawesi Sekatan. Bogor: Makaira Printing Plus

van den Ban AW, Hawkins HS. 1999. Penyuluhan Pertanian. Terjemahan, Herdiasti AD. Yogyakarta: Kanisius.

Wibowo. 2007. Manajemen Kinerja. Jakarta: Raja Grafindo Persada.

Wiriatmadja S. 1990. Pokok-Pokok Penyuluhan Pertanian. Jakarta: Yasaguna.

(YST) Yayasan Sinar Tani. 2001. Penyuluhan Pertanian. Jakarta: Yayasan Sinar Tani.

Bestina S, Slamet H, Amiruddin S. 2006. Kinerja Penyuluh Pertanian dalam Pengembangan Agribisnis Nenas di Kecamatan Tambang, Kabupaten Kampar. Laporan Hasil Penelitian. Kendari: Balai Pengkajian Teknologi Pertanian Kendari.

Sapar. 2011. "Faktor-Faktor yang Berpengaruh pada Kinerja Penyuluh Pertanian dan Dampaknya pada Kompetensi Petani Kakao di Empat Wilayah Sulawesi Selatan."J. Forum 
Pascasarjana, Vol 34 No. 4 hal: 297305

(BPSDM) Badan Pengembangan Sumberdaya Manusia Pertanian. 2007. Pedoman Penyelenggaraan Pendidikan dan Pelatihan Dasar Bagi Penyuluh Pertanian. Jakarta: BPSDM Deptan.

(Deptan) Departemen Pertanian. 1988. Pedoman Pengelolaan Balai Penyuluhan Pertanian. Jakarta: Departemen Pertanian. 